\title{
EGZEGEZA PATRYSTYCZNA W KATECHEZACH O PSALMACH JANA PAWŁA II I BENEDYKTA XVI*
}

Początkowo pragnąłem dokonać analizy porównawczej nauczania dwóch ostatnich papieży pod kątem wykorzystania w nim argumentacji patrystycznej. Za bazę źródłową zamierzałem przyjąć katechezy środowe podczas audiencji generalnych poświęcone komentowaniu poszczególnych psalmów zapoczątkowane przez Jana Pawła II i dokończone przez Benedykta XVI. Okazało się jednak, że takie porównanie jest niemożliwe, ponieważ, jak zapowiedział w pierwszej swojej katechezie Benedykt XVI, posłużył się on tekstami przygotowanymi wcześniej przez poprzednika ${ }^{1}$. Należy więc uznać całość środowych komentarzy do psalmów za dzieło jednego autora - Ojca Świętego Jana Pawła II, nawet jeżeli w szczegółach jego następca dokonał jakichś poprawek czy uzupełnień.

Stwierdziwszy, że porównanie sposobu wykorzystania argumentacji patrystycznej we wspomnianych katechezach przez obu papieży jest niemożliwe, nie chciałem jednak rezygnować z podjęcia analizy owych tekstów, gdyż stanowią one niezwykle interesujący materiał dla patrologa $\mathrm{z}$ racji obfitego i metodycznego, a nie przypadkowego, posłużenia się w nich literaturą patrystyczną, zwłaszcza egzegetyczną. Uznając więc, że mamy do czynienia z inicjatywą podjętą i przygotowaną przez Jana Pawła II, choć nie zaprezentowaną przez niego w całości osobiście, postaram się spojrzeć na środowe komentarze do psalmów pod trojakim kątem: doboru autorów patrystycznych, tematyki zaczerpniętej z ich dzieł oraz sposobu wykorzystania ich myśli egzegetycznej. Powyższe aspekty wytyczają zasadnicze punkty niniejszego opracowania. Najpierw jednak podam kilka informacji wstępnych dotyczących okoliczności wy-

" Pełne teksty tych katechez zob. w polskim wydaniu „Osservatore Romano” (OsRomPol) lub w książce: Psalmy. Jan Pawet II $i$ Benedykt XVI rozważają, wprowadzenie W. Chrostowski, Izabelin - Warszawa 2006, wyd. Rosikon Press (dalej cyt. Rozwazają Psalmy), lub na stronach internetowych: opoka.org.pl/nauczanie/papiez/jan_pawel_ii/audiencje.php oraz opoka.org.pl/nauczanie/papiez/benedykt_xvi/audiencje.php.

1 Por. Benedykt XVI, Psalm 121 - Bóg czuwa nad wiernymi 1 (4 V 2005), OsRomPol 26 (2005) nr 7-8, s. 25 lub Rozważają Psalmy, s. 361. 
głoszenia katechez, podstawowych danych liczbowych oraz charakterystyki gatunkowej papieskich wypowiedzi.

1. „Sitz im Leben” papieskich katechez o Psalmach. Podczas środowej audiencji generalnej w dniu 28 marca 2001 papież Jan Paweł II, odwołując się do konstytucji papieża Pawła VI Laudis canticum, zalecającej wyjaśnianie Ludowi Bożemu modlitw biblijnych, stanowiących podstawową strukturę Liturgii Godzin, zainaugurował cykl katechez poświęconych Psalmom i kantykom zawartym w Jutrzni i Nieszporach. Do końca pontyfikatu Jan Paweł II wygłosił 73 katechezy poświęcone Psalmom, nie licząc tych dotyczących kantyków, które pomijam w niniejszych analizach. Ostatnią katechezę o Psalmach wygłosił Jan Paweł II 15 grudnia 2004 roku. Jego następca podjął kontynuację cyklu; podczas audiencji środowej 4 maja 2005 r. poinformował, że będzie korzystał z rozważań przygotowanych przez swego poprzednika. Do 8 lutego 2006 r., kiedy została wygłoszona ostatnia katecheza poświęcona Psalmom Nieszporów, uczestnicy audiencji usłyszeli 26 wystąpień Benedykta XVI dotyczących Psalmów. W sumie obaj papieże poświęcili Psalmom 99 katechez.

Komentarze papieskie nie objęły wszystkich Psalmów, lecz jedynie te, które pojawiają się w liturgii Jutrzni i Nieszporów. Dotyczą one 75 Psalmów, a więc dokładnie połowy Psałterza ${ }^{2}$. W większości przypadków jeden psalm był przedmiotem rozważań podczas jednej katechezy. Z 10 Psalmów zostały skomentowane tylko fragmenty ${ }^{3}$. W 20 przypadkach temu samemu Psalmowi poświęcono dwie konferencje ${ }^{4}$, a psalm 51 został omówiony trzykrotnie.

We wszystkich wspomnianych katechezach papieże stosują tę samą metodę wykładu. Na wstępie krótko charakteryzują tematykę danego Psalmu, następnie omawiają jego strukturę i treść, sięgając często do etymologicznych wyjaśnień ważniejszych terminów hebrajskich. Egzegeza przebiega na trzech płaszczyznach: historycznej, teologicznej i moralno-duchowej. Bardzo silnie zaznaczony jest typologiczny charakter Psalmów i ich interpretacja chrystologiczna. Oparta na najnowszych osiągnięciach współczesnej biblistyki egzegeza każdego Psalmu jest niemal zawsze (z wyjątkiem 10 katechez) dopełniona w ostatniej części katechezy akcentem patrystycznym, zaczerpniętym z najważ-

${ }^{2}$ Komentarze papieskie nie objęły następujących Psalmów: 1, 2, 3, 4, 6, 7, 9, 10, 11, 12, 13, 14, $15,17,18,22,23,25,26,28,31,34,35,37,38,39,40,44,50,52,53,54,55,56,58,59,60,61,64,66,68$, $69,70,71,73,74,75,76,77,78,79,80,81,82,83,88,89,91,94,95,97,102,103,104,105,106,107$, 109, 114, 120,128, 129, 133, 134, 140.

${ }^{3}$ Były to następujące fragmenty Psalmów: 21, 2-8. 14; 49, 1-13; 112, 1-6; 137, 1-6; 138, 1-8; 141, $1-9 ; 142,2-3.6-8 ; 143,1-11 ; 144,1-10 ; 1471-11$.

${ }^{4}$ Dotyczy to Psalmów: 8, 51, 67, 100, 117, 118, 119, 135, 144, 147, 150 oraz Psalmów, które podzielono na dwie części: 27 (1-6; 7-14), 45 (2-10; 11-18), 72 (1-11; 12-19), 119 (105-112; 145-152), 132 (1-10; 11-18), 135 (1-12; 13-21), 136 (1-9; 10-26), 139 (1-3.5-6.11-12; 13-18.23-24); 145 (1-13; 14-21). 
niejszych dzieł egzegetycznych autorów wczesnochrześcijańskich. To zgodne ze scholastycznym wykładem prawd wiary, ale też postulowane przez najnowsze dokumenty Kościoła (Instrukcja Papieskiej Komisji Biblijnej o interpretacji Biblii w Kościele z 23 kwietnia 1993 r.), uzupełnianie danych biblijnych autorytatywnym komentarzem, pochodzącym z najstarszej tradycji kościelnej, jest charakterystyczną cechą katechez i zasługuje na szczególne uznanie z punktu widzenia posoborowego postulatu powrotu ,ad fontes”.

We wstępnej katechezie programowej, zatytułowanej nieprzypadkowo Psalmy w Tradycji Kościoła, wygłoszonej 28 marca 2001 r., papież Jan Paweł II wypowiedział znamienne słowa, doceniające wyjątkowy zmysł egzegetyczny, teologiczny, duchowy i pastoralny Ojców Kościoła. Oto słowa papieskiej deklaracji programowej ze wspomnianej katechezy wstępnej:

\begin{abstract}
„[...] Będą nam [...] pomocne odkrycia egzegezy, lecz wspólnie będziemy czerpać naukę z Tradycji, a zwłaszcza wsłuchiwać się w głos Ojców Kościoła. Oni to bowiem dzięki głębokiej duchowej wnikliwości potrafili odnaleźć i wskazać zasadniczy «klucz» do lektury Psalmów w samym Chrystusie, w głębi Jego tajemnicy. Ojcowie byli o tym głęboko przekonani: Psalmy mówią o Chrystusie. Rzeczywiście, zmartwychwstały Jezus odniósł do siebie słowa Psalmów, gdy rzekł do uczniów: «Musi się wypełnić wszystko, co napisane jest o Mnie w Prawie Mojżesza, u Proroków i w Psalmach» (Łk 24, 44). Ojcowie dodają, że w Psalmach mówi się do Chrystusa lub że wręcz przemawia sam Chrystus. Stwierdzając to, nie mieli na myśli tylko Osoby Jezusa, lecz Christus totus, całego Chrystusa, na którego składa się Chrystus głowa i Jego członki. Dlatego chrześcijanin może czytać Psalmy w świetle całej tajemnicy Chrystusa. Właśnie ta perspektywa pozwala dostrzec również ich wymiar eklezjalny, który w sposób szczególny podkreślony zostaje przez chóralny śpiew Psalmów"s.
\end{abstract}

W powyższej wypowiedzi programowej papież zwraca uwagę przede wszystkim na rozpowszechnioną, zwłaszcza w środowisku aleksandryjskim, chrystologiczną interpretację Psalmów, czyniąc z niej istotne narzędzie hermeneutyczne w swoich katechezach. Nawiązuje w ten sposób do rozpowszechnionej w Kościele od pierwszych wieków typologicznej lektury Starego Testamentu, ukierunkowanej na Chrystusa. Oprócz typologii chrystologicznej pojawiają się też w papieskich katechezach zapożyczone od Ojców wnioski moralne, duchowe i pastoralne, wyprowadzane na podstawie egzegezy poszczególnych Psalmów. W ten sposób papież ukazuje aktualność skojarzeń patrystycznych, osadzonych w realiach życia chrześcijan, ale równocześnie nacechowanych biblijnym radykalizmem i silnym ukierunkowaniem duchowym.

2. Patrystyczne źródła papieskich katechez o Psalmach. Patrystyczną bazę źródłową analizowanych katechez stanowi 112 fragmentów 60 dzieł 37 autorów

5 Jan Paweł II, Psalmy w tradycji Kościoła 2-3 (28 III 2001), OsRomPol 22 (2001) nr 5, s. 51-52. 
wczesnochrześcijańskich: 24 piszących po grecku ${ }^{6}, 12$ piszących po łacinie ${ }^{7}$ i jednego piszącego po syryjsku ${ }^{8}$. W trzech wystąpieniach Jan Paweł II powołał się ogólnie na autorytet Ojców Kościoła ${ }^{9}$. Przy doborze patrystycznych tekstów do papieskich katechez posłużono się dwojakim kryterium: wysokiej rangi autora oraz gatunku literackiego reprezentowanego przez wykorzystane dzieła, a są nimi najczęściej komentarze bądź homilie do Psalmów lub innych ksiąg biblijnych. Zdarzają się odstępstwa od tej zasady, polegające na przywołaniu pojedynczych cytatów z pism autorów mniej znanych oraz z dzieł nie mających charakteru egzegezy bezpośredniej, głównie dogmatycznych, ascetycznych i pastoralnych. Pierwsze z tych odstępstw pozwala poznać słuchaczom bogactwo postaci autorów wczesnochrześcijańskich, zwłaszcza ze środowiska mniszego; drugie uświadamia, że Ojcowie zawsze myśleli Biblią i była ona dla nich punktem wyjścia lub dojścia we wszelkiego rodzaju rozważaniach i formach piśmiennictwa.

Zdecydowane pierwszeństwo w katechezach przyznają papieże św. Augustynowi i jego monumentalnemu dziełu Enarrationes in Psalmos (23 przytoczenia) oraz Homiliae in Psalmos Orygenesa w łacińskim przekładzie i opracowaniu św. Hieronima (10 przytoczeń). 13 razy pojawiają się odwołania do dzieł św. Ambrożego: przede wszystkim do typowo egzegetycznych Expositiones in Psalmos, Expositio Evangelii secundum Lucam, ale także De Spiritu Sancto i De virginitate. Rzadziej korzystali papieże z pism: Bazylego Wielkiego (6 razy), Grzegorza Wielkiego (5 razy), Jana Chryzostoma (4 razy), Klemensa Rzymskiego ( 3 razy), Hieronima ( 3 razy), Euzebiusza z Cezarei (2 razy), Grzegorza z Nyssy (2 razy), Cyryla Jerozolimskiego (2 razy). Jeden raz zostali przywołani na podstawie dzieł apologetycznych, dogmatycznych, homiletycznych lub poetyckich następujący autorzy: Justyn, Cyprian, Klemens Aleksandryjski, Atanazy, Hilary z Poitiers, Dydym Ślepy, Grzegorz z Nazjanzu, Teodoret z Cyru, Paulin z Noli, Fulgencjusz z Ruspe, Piotr Chryzolog, Wenancjusz Fortunat i Beda Czcigodny. Osobną grupę stanowią moralne wskazówki nawiązujące do treści Psalmów zaczerpnięte z pism ascetycznych autorów z kręgu monastycznego: Jana Klimaka (1 raz), Barsanufiusza (3 razy), Izajasza z Gazy (2 razy),

${ }^{6}$ Należy do nich: Klemens Rzymski, List Barnaby, Justyn, Ireneusz, Klemens Aleksandryjski, Orygenes, Euzebiusz z Cezarei, Atanazy, Bazyli Wielki, Grzegorz z Nazjanzu, Grzegorz z Nyssy, Dydym Ślepy, Cyryl Jerozolimski, Jan Chryzostom, Cyryl Aleksandryjski, Teodoret z Cyru, Konstytucje Apostolskie, Barsanufiusz, mnich Izajasz z Gazy, anonim z Ojców Pustyni, Jan Klimak, Chryzyp z Jerozolimy, Hezychiusz z Jerozolimy, anonimowy autor palestyński z VIII wieku.

7 Należy do nich: Cyprian, Hilary z Poitiers, Ambroży, Paulin z Noli, Hieronim, Augustyn, Jan Kasjan, Fulgencjusz z Ruspe, Piotr Chryzolog, Grzegorz Wielki, Wenancjusz Fortunat, Beda Czcigodny.

8 Jest to Efrem Syryjski.

${ }^{9}$ Bez przytaczania konkretnych dzieł wymienił nazwiska nie cytowanych w innych miejscach autorów: Maksyma Wyznawcy, Jana Damasceńskiego, Germana z Konstantynopola i Chromacjusza z Akwilei. 
Jana Kasjana (3 razy) i Hezychiusza z Jerozolimy (1 raz). Wczesnochrześcijańską literaturę syryjską reprezentują trzykrotnie zacytowane hymny Efrema Syryjskiego, nawiązujące do wielbiąco-dziękczynnego charakteru Psalmów.

Z powyższego zestawienia wynika, że papieże sięgnęli w swoich katechezach do najważniejszych dzieł patrystycznych nawiązujących do psalmów. Zdziwienie może budzić tylko brak wykorzystania ogromnego kompletnego późnopatrystycznego komentarza do Psalmów Expositio psalmorum Kasjodora. Dzieło to $\mathrm{z}$ niezrozumiałych względów wciąż czeka na ponowne odkrycie i dowartościowanie przez biblistów ${ }^{10}$. Na uwagę zasługuje częste powoływanie się w katechezach na słynny w starożytności Komentarz do Psalmów Orygenesa w przekładzie i opracowaniu Hieronima oraz nazywanie ,wielkim pisarzem chrześcijańskim" teologa kontrowersyjnego z punktu widzenia dotyczących go w starożytności orzeczeń kościelnych. Jest to jeden z wielu przykładów - obok umieszczenia tekstów Aleksandryjczyka w Liturgii Godzin czy Katechizmie Kościoła Katolickiego - posoborowej rehabilitacji jego genialnej myśli, przerastającej ówczesne czasy. Przywoływanie interpretacji Orygenesa w papieskich katechezach nie jest przypadkowe, nawiązują one bowiem przede wszystkim do chrystologicznej i duchowej egzegezy tekstów starotestamentalnych, której aleksandryjski egzegeta był mistrzem.

3. Tematyka zaczerpnięta $\mathrm{z}$ pism patrystycznych. Papieskie katechezy do Psalmów sięgają do tekstów patrystycznych w celu wydobycia $z$ nich przede wszystkim celnych wniosków egzegetycznych dotyczących poszczególnych Psalmów. Tematykę zapożyczoną z pism Ojców można podzielić na trzy grupy. Najliczniejszą stanowią interpretacje chrystologiczne, co stanowi potwierdzenie słuszności i aktualności najstarszego, sięgającego czasów apostolskich nurtu przenośnej interpretacji Starego Testamentu, jaki stanowiła typologia chrystologiczna. Przykładowo autorzy katechez przywołują teksty Jana Chryzostoma $^{11}$, Augustyna ${ }^{12}$, Jana Kasjana ${ }^{13}$, odnoszące do Chrystusa następujące wersety Psalmów: «Tyś najpiękniejszy z synów ludzkich, wdzięk rozlał się na twoich wargach: przeto pobłogosławił tobie Bóg na wieki» (Ps 45 [44], 3), „O Boże, przekaż Twój sąd królowi i Twoją sprawiedliwość synowi królewskiemu” (Ps 72 [71], 1), „Nachyl swych niebios i zstąp po nich, Panie” (Ps 144).

${ }^{10}$ Por. opublikowane ostatnio cenne opracowanie filologiczne dzieła Kasjodora: K. Burczak, Figury retoryczne i tropy w Psalmach na podstawie „Expositio Psalmorum” Kasjodora, Lublin 2004.

11 Por. Joannes Chrisostomus, Expositiones in Psalmos 44, 4; Jan Paweł II, Psalm 45, 2-10 zaślubiny króla (1) 5, (29 IX 2004), OsRomPol 26 (2005) nr 1, s. 45; Rozważają Psalmy, s. 116.

12 Por. Augustinus, Enarrationes in Psalmos 71, 14; Jan Paweł II, Psalm 72, 12-19 - królestwo pokoju i błogosławieństwa 4 (15 XII 2004), OsRomPol 26 (2005) nr 3, s. 41; Rozważają Psalmy, s. 190.

${ }^{13}$ Por. Joannes Cassianus, De incarnatione Domini 5, 13; Jan Paweł II, Psalm 11, 1-10 modlitwa o zwycięstwo i pokój 5 (21 V 2003), OsRomPol 24 (2003) nr 10, s. 49; Rozwazaja Psalmy, s. 22. 
Do powyższej tematyki nawiązują również odniesienia słów Psalmów na zasadzie typologii do Kościoła. Jan Paweł II przywołuje na przykład interpretację św. Augustyna, który zwracając uwagę na tytuł poprzedzający Psalm 5: „Tej, która otrzymuje dziedzictwo", wyjaśnia, że chodzi o Kościół, który otrzymuje dziedzictwo życia wiecznego za pośrednictwem Jezusa Chrystusa ${ }^{14}$.

Drugą grupę tematyczną wśród odwołań papieży do egzegetycznej literatury patrystycznej stanowią przytoczenia ich interpretacji duchowej Psalmów, odnoszącej poszczególne wersety do życia moralno-duchowego chrześcijan. Werset z Psalmu 147 - „Pan leczy złamanych na duchu” - Augustyn rozumie jako zachętę do skruchy serca i pokory ${ }^{15}$, na którą to cnotę wskazuje wiele komentarzy, np. Jana Kasjana, Fulgencjusza z Ruspe i Ambrożego. Cyryl Jerozolimski wykorzystuje Psalm 32 jako zachętę dla katechumenów do radykalnego oczyszczenia się z wszelkiego grzechu ${ }^{16}$. Wiele przywołanych patrystycznych interpretacji Psalmów dotyczy pogłębionej relacji chrześcijanina z Bogiem. W przekonaniu Augustyna pod obrazem morza uspokajanego przez Pana kryje się dzisiejszy świat ${ }^{17}$. Według Orygenesa stawianie przenośnych namiotów w drodze z Psalmu 27 to obraz nieustannego poszukiwania Boga przez człowieka ${ }^{18}$. Do tej grupy tematycznej można zaliczyć porady mnichów, którzy zalecali rozważanie konkretnych wersetów Psalmów w różnych trudnych sytuacjach życiowych. Przykładowo Barsanufiusz z Gazy pokrzepiał ludzi zgnębionych nieszczęściami wierszem z Psalmu 121 - „Pan cię ochroni od zła wszelkiego, ochroni twoją duszę" 19 .

Trzecią grupę tematyczną, najmniej liczną, tworzą wezwania modlitewne o charakterze podobnym do analizowanych Psalmów (hymn wieczorny z Konstytucji Apostolskich nawiązuje do klimatu uwielbienia Boga z Psalmu 113) ${ }^{20}$ lub zachęty do modlitwy w duchu uwielbienia lub dziękczynienia reprezentowanym przez dany Psalm (radosny hymn Psalmu 124 Augustyn odnosi do członków Kościoła i zbawionych w niebie $\left.{ }^{21}\right)$.

14 Por. Augustinus, Enarrationes in Psalmos 5, 1; Jan Paweł II, Poranna modlitwa o pomoc Pana 1 (30 V 2001), OsRomPol 22 (2001) nr 7-8, s. 53; Rozważają Psalmy, s. 6.

15 Por. Augustinus, Enarrationes in Psalmos 146, 5-8; Jan Paweł II, Psalm 147a - Boża potęga i dobroć 2 (23 VII 2003), OsRomPol 24 (2003) nr 11-12, s. 34; Rozważają Psalmy, s. 456.

16 Por. Cyrillus Hierosolymitanus, Procatechesis 15; Jan Paweł II, Psalm 32 - szczęście uwolnionego od winy 5 (19 V 2004), OsRomPol 25 (2004) nr 7-8, s. 50; Rozważają Psalmy, s. 76.

17 Por. Augustinus, Enarrationes in Psalmos 64, 3; Jan Paweł II, Psalm 65 - radość stworzeń z Opatrzności Bożej 3 (6 III 2002), OsRomPol 23 (2002) nr 6, s. 36; Rozważają Psalmy, s. 169.

18 Por. Origenes, Homiliae in Numeros 17, 4; Jan Paweł II, Psalm 27, 7-14 - Bóg moim świattem (2) 5 (28 IV 2004), OsRomPol 26 (2005) nr 6, s. 35; Rozważaja Psalmy, s. 62.

19 Por. Barsanuphius e Gaza, Epistulae 194; Benedykt XVI, Psalm 121 - Bóg czuwa nad wiernymi 4 (4 V 2005), OsRomPol 26 (2005) nr 7-8, s. 25-26; Rozwazaja Psalmy, s. 362.

20 Por. Constitutiones Apostolicae VII 48; Benedykt XVI, Psalm 113 - chwalebne jest imię Pana 5 (18 V 2005), OsRomPol 26 (2005) nr 7-8, s. 28; Rozważają Psalmy, s. 312.

21 Por. Augustinus, Enarrationes in Psalmos 123, 3; Benedykt XVI, Psalm 124 - Bóg ocaleniem Izraela 4 (22 VI 2005), OsRomPol 26 (2005) nr 10, s. 46; Rozważają Psalmy, s. 371. 
Niektóre rozważania egzegetyczne Ojców zostały dobrane pod kątem ważnych współczesnych problemów i są dowodem ciągłej aktualności myśli patrystycznej. Na przykład w katechezie o Psalmie 72 została przywołana medytacja Augustyna, korespondująca z posoborową wizją Kościoła otwartego. Augustyn zwraca w niej uwagę, że wśród pogańskich królów są osoby, które dostrzegając swoją słabość i grzeszność, niejako podświadomie poszukują Zbawiciela i zbliżają się do Chrystusa ${ }^{22}$.

\section{Sposób wykorzystania patrystycznej egzegezy w papieskich katechezach.}

W papieskich katechezach do Psalmów teksty patrystyczne pojawiają się najczęściej w ostatniej części, pełniąc rolę argumentu z Tradycji, jak w typowym scholastycznym wykładzie. Są jedynym źródłem pomocniczym w papieskiej egzegezie, co świadczy o tym, że papieże uznają je za autorytatywne i w pewnym sensie wystarczające w zakresie sposobu interpretacji tekstu biblijnego na użytek wiernych. Cel wykorzystania komentarzy Ojców jest dwojaki i odpowiada celowi, jaki stawiała sobie egzegeza patrystyczna w wydaniu aleksandryjskim, która wywarła największy wpływ na interpretację Biblii także w środowisku autorów łacińskich. Celem tym jest z jednej strony doprowadzenie czytelnika Psalmów do Chrystusa, który w nich sam się modli i antycypuje swoją ziemską drogę cierpienia i chwały, posłuszeństwa Ojcu i wielbienia Go. $\mathrm{Z}$ drugiej strony tekst Psalmów ma, w zamierzeniu papieży, doprowadzić odbiorców za pośrednictwem duchowej egzegezy Ojców do moralnej dojrzałości i duchowej doskonałości, a także nauczyć zwracania się do Boga w różnych okolicznościach życia. Podobnie jak dla wielu Ojców Kościoła lektura każdego tekstu biblijnego musiała prowadzić przez Chrystusa do człowieka i pomagać mu na nowo zjednoczyć się z Bogiem (wszak za podstawowe kryterium interpretacyjne uznawali ỏ $\phi \dot{\lambda} \lambda \varepsilon \iota \alpha$, czyli korzyść duchową odbiorcy), tak też papieże, korzystając z tej zasady patrystycznej, próbują słowami samych Ojców jako najlepszych specjalistów, przyprowadzić czytelnika Psalmów najpierw do Chrystusa, a następnie pomóc mu wyciągnąć wraz z Chrystusem wnioski duchowe i pastoralne dla siebie.

Oprócz rozbudowanych wyjaśnień alegorycznych, odnoszących kolejne wersety Psalmów do Jezusa cierpiącego, zmartwychwstałego, królującego, prowadzącego swój lud do niebieskiego Jeruzalem lub zachęcających do praktykowania cnót, zwłaszcza pokory, pojawiają się w katechezach krótkie komentarze alegoryczne odnoszące się do poszczególnych terminów i zwrotów, zwłaszcza obrazowych, stanowiące swoisty rodzaj przewodnika po symbolice Psalmów. Na przykład Jan Paweł II odwołuje się do Augustyna, który w swych

22 Por. Augustinus, Enarrationes in Psalmos 71, 14; Jan Paweł II, Psalm 72, 12 -19 - królestwo pokoju i błogosławieństwa 4 (15 XII 2004), OsRomPol 26 (2005) nr 3, s. 41; Rozważają Psalmy, s. 190. 
Enarrationes in Psalmos interpretuje instrumenty muzyczne, występujące w psalmach jako symbole świętych, oddających chwałę Bogu, a także jako obraz czynów spełnianych przez dobrych uczniów Jezusa:

„Wy, święci, jesteście trą̨ą, harfą, cytrą, bębenkiem, chórem, strunami, i organami, i cymbałem radości mile dźwięczącym, ponieważ współdźwięczącym” ”23; „Cytra jest rodzajem instrumentu, który posiada struny. Czyn nasz to nasza cytra. Ktokolwiek spełnia rękami dobre uczynki, śpiewa psalm Bogu"24.

Natomiast na Orygenesowe Homilie do Psalmów w przekładzie i opracowaniu Hieronima powołuje się papież Jan Paweł II tłumacząc zwrot „,wyborna pszenica" z Psalmu 147 jako znak Chrystusa, który, zgodnie z ulubionym przekonaniem Aleksandryjczyka, karmi chrześcijanina nie tylko swoim rzeczywistym Ciałem, ale przede wszystkim słowem Pisma Świętego, które jest Jego Ciałem duchowym ${ }^{25}$.

Zasadniczo teksty patrystyczne w katechezach do Psalmów dopełniają, potwierdzają lub ilustrują egzegezę papieży. Zdarzają się jednak także nieliczne przypadki zastąpienia własnej egzegezy aktualizującej przytoczeniem obszernego fragmentu interpretacji patrystycznej danego Psalmu (np. Augustyna w odniesieniu do Psalmu $124^{26}$ czy Ambrożego do Psalmu $119^{27}$ ). Przypominają one zasadę przedstawioną w De doctrina christiana przez Augustyna ${ }^{28}$, a stosowaną często w praktyce przez znanego ludowego kaznodzieję wczesnochrześcijańskiej Galii - Cezarego z Arles. Dopuszczała ona możliwość czytania dużego fragmentu lub nawet całej homilii jakiegoś Ojca Kościoła, jeżeli kaznodzieja uznawał, że sam nic nowego już nie wymyśli i nie zdoła tego lepiej wyrazić ${ }^{29}$.

23 Por. Augustinus, Enarrationes in Psalmos 150, 8; Jan Paweł II, Psalm 150 - chwalcie Pana 5 (26 II 2003), OsRomPol 24 (2003) nr 5, s. 49; Rozważaja Psalmy, s. 475.

${ }^{24}$ Por. Augustinus, Enarrationes in Psalmos 91, 5; Jan Paweł II, Psalm 92 -doskonatość Boża 1 (3 IX 2003), OsRomPol 25 (2004) nr 3, s. 34; Rozwazają Psalmy, s. 245.

25 Por. Origenes - Hieronymus, Homiliae in Psalmos 147, 14; Jan Paweł II, Psalm 147 Jeruzalem wielbi Boga 1 (5 VI 2002), OsRomPol 23 (2002) nr 10-11, s. 42; Rozwazaja Psalmy, s. 458 ,

26 Por. Augustinus, Enarrationes in Psalmos 123, 3; Benedykt XVI, Psalm 124 - Bóg ocaleniem Izraela 4 (22 VI 2005), OsRomPol 26 (2005) nr 10, s. 46; Rozważaja Psalmy, s. 371.

27 Por. Ambrosius, Expositiones in Psalmos 118, 2; Jan Paweł II, Psalm 119, 145-152 - prośba o wierność przykazaniom 3-4 (15 I 2003), OsRomPol 24 (2003) nr 3, s. 37-38; Rozważają Psalmy, s. 354-355.

${ }^{28}$ Por. Augustinus, De doctrina christiana IV 29; zob. E. Staniek, Sekrety dobrego kaznodziejstwa w ujęciu św. Augustyna, RBL 42 (1989) s. 306.

${ }^{29}$ Por. E. Stanula, Chrześcijanie, do których przemawiat św. Cezary z Arles (wstęp), w: Sw. Cezary z Arles, Kazania, PSP 52, Warszawa 1989, 10-11; M. Szram, Homilia i kazanie patrystyczne jako wzorzec dla wspótczesnych kaznodziejów, w: Integralne ksztatcenie kaznodziei, red. W. Broński, Lublin 2006, 165. 
Katechezy do Psalmów Jutrzni i Nieszporów, wygłaszane przez Jana Pawła II i Benedykta XVI, zostały przygotowane za pontyfikatu polskiego papieża, chociaż z pewnością ich nachylenie ku patrystyce bliskie było także, a może jeszcze bardziej jego następcy - teologowi, miłośnikowi Ojców Kościoła, znawcy pism św. Augustyna. Zasługą Jana Pawła II jako pomysłodawcy cyklu było udostępnienie wiernym w cotygodniowym nauczaniu egzegezy Ojców doskonale łączącej naukowe i duchowe podejście do tekstu biblijnego. Katechezy stanowią przykład właściwie pojętej realizacji soborowego postulatu powrotu do źródeł, ukazują bowiem nierozerwalny związek Pisma Świętego z komentarzem Tradycji, będącym jego autorytatywną wykładnią. Obszerna ilość zaprezentowanych w katechezach sylwetek wczesnochrześcijańskich egzegetów największych i mniej znanych - była okazją dla przeciętnego chrześcijanina uczestniczącego w audiencjach do poznania bogactwa literatury wczesnochrześcijańskiej. Wyeksponowanie aspektów: chrystologicznego i duchowego patrystycznej egzegezy pokazuje, w jakim kierunku powinna iść współczesna interpretacja Pisma Świętego: ta uprawiana przez teologów i ta wypływająca z modlitewnej lektury Biblii przez wszystkich członków Kościoła. Papież Jan Paweł II wskazując na wspomniane dwie linie interpretacyjne nawiązał w swoich katechezach przede wszystkim do egzegezy wywodzącej się z sięgającego czasów apostolskich nurtu typologii chrystologicznej, rozwiniętego i uzupełnionego o alegoryczną egzegezę duchową w środowisku aleksandryjskim, będącym inspiracją dla największych egzegetów patrystycznego Wschodu i Zachodu. Tym samym papież pośrednio wskazał na aktualność tej egzegezy dzisiaj i jej większą przydatność dla życia moralno-duchowego chrześcijan niż egzegezy czysto literalnej o nastawieniu historycznym, reprezentowanej w starożytności chrześcijańskiej przez środowisko antiocheńskie. W tym kontekście należy przypomnieć stwierdzenie J.H. Newmana, które wydaje się najlepszym komentarzem i podsumowaniem kryterium doboru tekstów Ojców do omawianych papieskich katechez i sposobu wykorzystania w nich egzegezy patrystycznej: „Można to prawie uważać za fakt historyczny, że interpretacja mistyczna i ortodoksyjna [Pisma Świętego] są trwale związane ze sobą. [...] wszyscy, którzy zachowali wiarę Kościoła, nigdy nie wyzbyli się duchowego sensu Pisma Świętego. [...] posługiwanie się Pismem Świętym, zwłaszcza w jego znaczeniu duchowym, [...] jako ośrodkiem myśli i dedukcji, jest charakterystyczną zasadą nauczania doktrynalnego w Kościele" ${ }^{\text {30. }}$.

30 J.H. Newman, O rozwoju doktryny chrześcijańskiej, tłum. J.W. Zielińska, Warszawa 1957, 360-363. 


\section{EXEGESE PATRISTIQUE DANS LES CATECHESES SUR LES PSAUMES DES PAPES JEAN PAUL II ET BENOIT XVI}

(Resumé)

Quatre-vingt-dix-neuf catécheses sur les Psaumes des Laudes et Vepres, proclamées par les papes Jean Paul II et Benoît XVI entre 28 mars 2001 et 8 février 2006, furent preparées pendant le pontificat du pape polonais. Comme inventeur du projet Jean Paul II presantait aux fidèles chaque semaine dans son enseignement l'exégèse des Pères de l'Église, qui joint parfaitement l'interprétation scientifique et spirituelle du texte sacré. Les catecheses sont un exemple de bonne réalisation du postulat du Concil Vatican II du „retour ad fontes”, parce que elles montrent des liens très stricts entre l'Écriture sainte et les commentaires respectueux de la Tradition ecclésiastique. Grande nombre de 37 auteurs patristiques - plus ou moins connus - presentés dans les catécheses fut une occasion pour les participants aux audiences papales de faire une connaissance de la richesse de la littérature de l'Église primitive. L'exposition des deux aspects - christologique et spirituel - de l'exégèse patristique montre la direction de l'interprétation contemporaine de l'Écriture sainte non seulement pour les théologiens, mais aussi pour tous les membres de l'Église qui doivent prier avec les textes bibliques. Le pape Jean Paul II évoquait surtout la méthode de typologie christologique très repandue aux premiers siècles du christianisme, élargie par l'exégèse spirituelle dans le milieu alexandrin, qui formait une source d'inspiration pour tous les plus grands exégètes patristiques en Orient et en Occident. En même temps le pape montrait l'actualité de cette exégèse pour notre époque d'aujourd'hui et son utilité pour la vie morale et spirituelle des chrétiens, beaucoup plus grande que celle de l'exégèse littérale et historique, representée dans l'antichité chrétienne par le milieu antiochien. 